\title{
Photocatalytic Degradation of 1,4-Benzoquinone in Aqueous ZnO Dispersions
}

\author{
Yadollah Abdollahi, *,a Abdul H. Abdullah, ${ }^{a, b}$ Umar I. Gaya, ${ }^{b}$ Saeid Ahmadzadeh, ${ }^{b}$ Azmi Zakaria, ${ }^{a, b}$

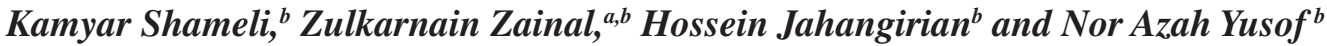 \\ ${ }^{a}$ Advanced Materials and Nanotechnology Laboratory, Institute of Advanced Technology and \\ ${ }^{b}$ Department of Chemistry, Faculty of Science, \\ Universiti Putra Malaysia, 43400 Serdang, Selangor D. E., Malaysia
}

\begin{abstract}
O presente artigo relata a degradação UV-assistida de 1,4-benzoquinona em suspensões ZnO. As variáveis estudadas incluem a concentração de 1,4-benzoquinona, fotocatalisador, $\mathrm{pH}$ e carbono orgânico total. A concentração de 1,4-benzoquinona e o carbono orgânico residual foram medidos usando espectrofotômetro UV-Visível e analisador TOC, respectivamente. Os resultados mostraram que a fotodegradação da 1,4-benzoquinona foi independente do $\mathrm{pH}$. A fotoatividade do $\mathrm{ZnO}$ foi máxima na concentração de $1,0 \mathrm{~g} \mathrm{~L}^{-1}$ e em níveis de $100 \mathrm{mg} \mathrm{L}^{-1}$ de 1,4-benzoquinona. Na faixa de $\mathrm{pH}$ 4-10 mais de $80 \%$ de 1,4-benzoquinona pode ser removida. $\mathrm{ZnO}$ demonstrou capacidade de reutilização no processo.
\end{abstract}

The present paper reports the UV-assisted degradation of 1,4-benzoquinone in $\mathrm{ZnO}$ suspensions. The variables studied include the concentration of 1,4-benzoquinone, photocatalyst, $\mathrm{pH}$ and the total organic carbon. The concentration of 1,4-benzoquinone and residue organic carbon were measured using UV-Visible spectrophotometer and TOC analyzer, respectively. The results showed that 1,4-benzoquinone photodegradation was independent of $\mathrm{pH}$. The photoactivity of $\mathrm{ZnO}$ was maximum at $1.0 \mathrm{~g} \mathrm{~L}^{-1}$ concentration and at $100 \mathrm{mg} \mathrm{L}^{-1}$ 1,4-benzoquinone levels. Within $\mathrm{pH}$ 4-10 more than $80 \%$ of 1,4 -benzoquinone can be removed. $\mathrm{ZnO}$ has demonstrated reusability in the process.

Keywords: photocatalytic degradation, benzoquinone, mineralization, $\mathrm{ZnO}$

\section{Introduction}

Photocatalysis is a subject of interest in view of its prosperous application in pollutant decontamination. Photocatalysis takes the advantage of the ability of semiconductor photocatalyst to generate surface bound hydroxyl radical and trapped hole upon excitation by band gap light. One important feature of these photogenerated species is that they are capable of degrading a wide variety of organic compounds owing to their oxidizing power. ${ }^{1-5}$ Among the several semiconductor photocatalysts used, $\mathrm{TiO}_{2}$ has been considered the most superior in terms of suitability for application. ${ }^{6,7}$ The current interest in $\mathrm{ZnO}$ is based on its high spectral response in both UV and visible region which presumably, in some studies, resulted in higher efficiency of photocatalytic degradation well over $\mathrm{TiO}_{2} \cdot{ }^{8-12}$ Based on the aforementioned, $\mathrm{ZnO}$ photocatalysis has been proposed as an alternative in the removal of various aqueous pollutants including phenolic compounds. ${ }^{13-20}$

Even though benzoquinone has been reported as an intermediate of the degradation of aromatic compounds from different organic classes the case of 1,4-benzoquinone individually as potential pollutant has not yet been paid much attention. ${ }^{20-25}$ Sobczyński et al. ${ }^{26}$ have investigated the photodegradation of 1,4-benzoquinone in $\mathrm{TiO}_{2}$ suspensions. The rate of disappearance of the initial benzoquinone was very slow. Actually, only $14 \%$ of the starting benzoquinone was mineralized in $240 \mathrm{~min}$ while the rest was converted to intermediates, mainly hydroquinone. We therefore aimed the investigation of the photocatalytic destruction of 1,4-benzoquinone (1,4-BQ) in $\mathrm{ZnO}$ dispersions with the expectation of a better mineralization process.

*e-mail: yadollahabdollahi@yahoo.com 


\section{Experimental}

\section{Chemicals and apparatus}

High grade chemicals were used in the study, as received. These chemicals include zinc oxide $(99 \%$, Merck) and 1,4-BQ (99\%, ACROS). $\mathrm{CH}_{2} \mathrm{Cl}_{2}$ (99.95\%) was used for the extraction of intermediate products and the extracts were dried using $\mathrm{Na}_{2} \mathrm{SO}_{4}$. The $\mathrm{ZnO}$ has a surface area of $3.3 \mathrm{~m}^{2} \mathrm{~g}^{-1}$ that measured by static BET using Thermo Finnigan Sorptomatic 1990 Series analyzer. The particle size of $\mathrm{ZnO}$ recorded on Nanophox facility was 0.4-0.5 $\mu \mathrm{m}$. Band gap measured using Perkin Elmer Lambda 35 UV-Vis-NIR was $3.02 \mathrm{eV}$. pH was adjusted using $\mathrm{H}_{2} \mathrm{SO}_{4}$ and $\mathrm{NaOH}$. All preparations were made using deionized water. Photocatalytic experiments were performed in a non-continuous mode (batch) reactor (Figure 1) fitted with $6 \mathrm{~W}$ UV-A lamp. The $\mathrm{pH}$ of the experimental solution was determined using a pre-calibrated DELTO $\mathrm{pH}$ meter.

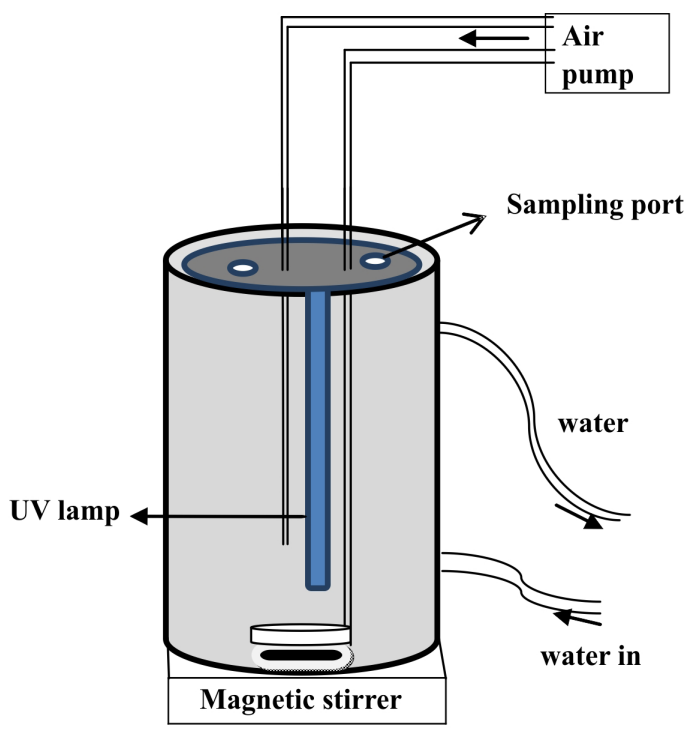

Figure 1. Schematic diagram of the batch reactor used in the study.

Methods

In all photocatalytic experiments, a mixture of known quantities of $\mathrm{ZnO}$ and 1,4-BQ was irradiated for $60 \mathrm{~min}$. The mixture was magnetically stirred to maintain even distribution of suspension throughout the reactor. At specific time intervals, samples were withdrawn from the bulk solution and filtered through a $0.45 \mu \mathrm{m}$ polytetrafluroethylene (PTFE) membrane. In order to compare the efficiency of the photocatalytic degradation of 1,4-BQ, the filtrates were analysed by UV-Vis spectrometry and Gas chromatography-Mass spectrometry (GC-MS). The concentration of the unreacted 1,4-BQ was analyzed with UV-Vis spectrophotometer (Shimadzu, UV-1650pc) at the maximum absorption wavelength of 1,4-BQ (246 nm). Aromatic intermediates were identified by GC-MS using a Hewlett-Packard 5890 Series II gas chromatograph fitted with an Elite-5MS column $(30 \mathrm{~m} \times 0.25 \mathrm{~mm} \times 0.25 \mu \mathrm{m})$ and a Hewlett-Packard 5989A mass spectrophotometer operating in EI mode at $70 \mathrm{eV}$. The column temperature was $40{ }^{\circ} \mathrm{C}$ (held for $1 \mathrm{~min}$ ), then ramped at $10{ }^{\circ} \mathrm{C} \mathrm{min}{ }^{-1}$ to $240{ }^{\circ} \mathrm{C}$ (held for one min). The total organic carbon in the samples was determined using ANATOC series II total organic carbon analyzer. Parallel experiments were run at the same time and under the same conditions. The percentage photodegradation of 1,4-BQ was calculated using equation 1 ,

Photodegradation $(\%)=\frac{\left(\mathrm{C}_{\mathrm{o}}-\mathrm{C}\right)}{\mathrm{C}_{\mathrm{o}}} \times 100$

where $\mathrm{C}_{\mathrm{o}}=$ initial concentration of 1,4-BQ and $\mathrm{C}=$ concentration of $1,4-\mathrm{BQ}$ after photo-irradiation.

\section{Results and Discussion}

\section{Preliminary studies}

The photodegradation of 1,4-BQ was first investigated in the absence of $\mathrm{ZnO}$. It was found that under such condition, the maximum loss of 1,4-BQ was $16 \%$. Hence, $1,4-\mathrm{BQ}$ is apparently fairly unstable under UV irradiation. In order to determine the effect of adsorption, the change in the concentration of 1,4-BQ in the presence of $\mathrm{ZnO}$ was monitored in the dark. The initial concentration of 1,4-BQ decreased by $10 \%$ due mainly to adsorption of 1,4-BQ onto the $\mathrm{ZnO}$ surface. In both studies, the starting concentration of 1,4-BQ was $100 \mathrm{mg} \mathrm{L}^{-1}$.

\section{Effect of 1,4-BQ concentration}

To determine the effect of substrate concentration, the photocatalytic degradation of 1,4-BQ at various initial concentrations (100-250 $\mathrm{mg} \mathrm{L}^{-1}$ ) was studied for $60 \mathrm{~min}$. The degradation of $1,4-\mathrm{BQ}$ at these concentrations is shown in Figure 2. It would be clearly seen that the amount of 1,4-BQ degraded starts decreasing as substrate concentration reaches $150 \mathrm{mg} \mathrm{L}^{-1}$. This decrease can be attributed to reduced photo absorption by the catalyst probably as a result of excess 1,4-BQ in solution. ${ }^{13}$ Put simply, the amount of 1,4-BQ attacked by $\mathrm{h}^{+}$or ${ }^{\cdot} \mathrm{OH}$ declines as the generation of the latter is limited by catalyst concentration and irradiation. ${ }^{27}$ Further phototoexperiments were therefore carried out at $100 \mathrm{mg} \mathrm{L}^{-1}$. 


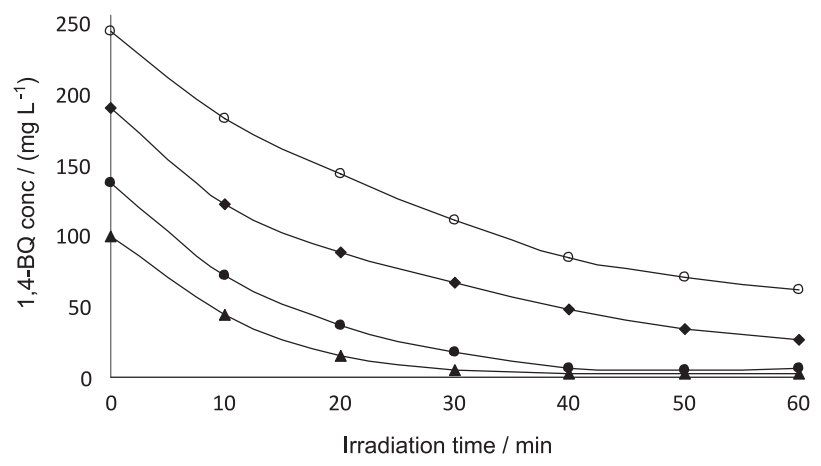

Figure 2. Effect of 1,4-BQ concentration on degradation efficiency, (४) $100 \mathrm{mg} \mathrm{L}^{-1},(\bullet) 150 \mathrm{mg} \mathrm{L}^{-1},(\diamond) 200 \mathrm{mg} \mathrm{L}^{-1}$, (○) $250 \mathrm{mg} \mathrm{L}^{-1}$, initial condition: $\mathrm{ZnO}=1.0 \mathrm{~g} \mathrm{~L}^{-1}, \mathrm{pH} 7.55$ and $25^{\circ} \mathrm{C}$.

\section{Effect of photocatalyst loading}

Series of experiments were carried out by varying the catalyst concentration from $0.5 \mathrm{~g} \mathrm{~L}^{-1}$ to $4.0 \mathrm{~g} \mathrm{~L}^{-1}$ so as to observe the effect of the catalyst loading. Figure 3 shows photodegradation of 1,4-BQ in presence of different concentrations of $\mathrm{ZnO}$ over $60 \mathrm{~min}$. From the figure, the percentage of 1,4-BQ degraded was enhanced by increasing the concentration of $\mathrm{ZnO}$. This can be attributed to an increase in the effective surface of the photocatalyst, consequently enhancing hydroxyl radical formation. Maximum degradation (corresponding to about $100 \%$ degradation) of 1,4-BQ was observed at $1.0 \mathrm{~g} \mathrm{~L}^{-1}$ $\mathrm{ZnO}$. There was decrease in photodegradation percentage at higher catalyst concentrations. This decrease in the efficiency as the optimum catalyst loading is exceeded $\left(1.0 \mathrm{~g} \mathrm{~L}^{-1}\right)$ may be attributed to the screening effect by excess photocatalyst particles in the solution. ${ }^{28}$

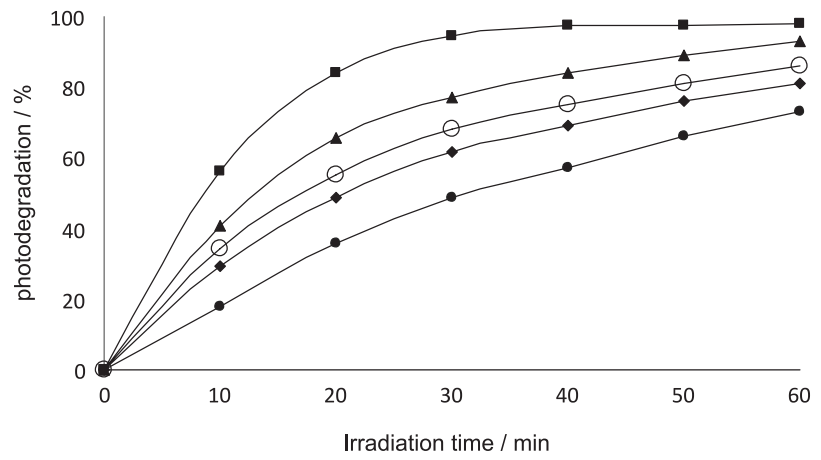

Figure 3. Effect of photocatalyst concentration on the degradation of 1,4-BQ at $25{ }^{\circ} \mathrm{C}$. $[1,4-\mathrm{BQ}]=100 \mathrm{mg} \mathrm{L}^{-1}$, initial $\mathrm{pH}=7.55$. Legend: $\bullet=0.5 \mathrm{~g} \mathrm{~L}^{-1}, \boldsymbol{\square}=1.0 \mathrm{~g} \mathrm{~L}^{-1}, \boldsymbol{\Lambda}=2.0 \mathrm{~g} \mathrm{~L}^{-1}, \bigcirc=3.0 \mathrm{~g} \mathrm{~L}^{-1}, \bullet=4.0 \mathrm{~g} \mathrm{~L}^{-1}$.

\section{Effect of $\mathrm{pH}$}

The effect of $\mathrm{pH}$ (4-10) on the photodegradation of 1,4-BQ was studied at optimum amount of $\mathrm{ZnO}$ and 1,4-BQ as obtained from the previous experiments. Figure 4 shows the effect of $\mathrm{pH}$ on the photodegradation of 1,4-BQ. Although the maximum photodegradation was obtained at $\mathrm{pH} 9$ $(100 \%)$, it would be observed that the relative difference in the effect of $\mathrm{pH}$ on the 1,4-BQ photodegradation under the conditions of the study is insignificant. This is likely due to the fact that in alkaline solution ( $\mathrm{pH} 8-9),{ }^{\circ} \mathrm{OH}$ is easier to regenerate on the photocatalyst surface.$^{13}$ However, the amount of 1,4-BQ degraded decreased at $\mathrm{pH} 10$, perhaps due to the presence of ${ }^{\circ} \mathrm{OH}$ radical scavengers, ${ }^{29}$ such as $\mathrm{H}_{2} \mathrm{O}_{2}$ which can generate weaker oxidising species.

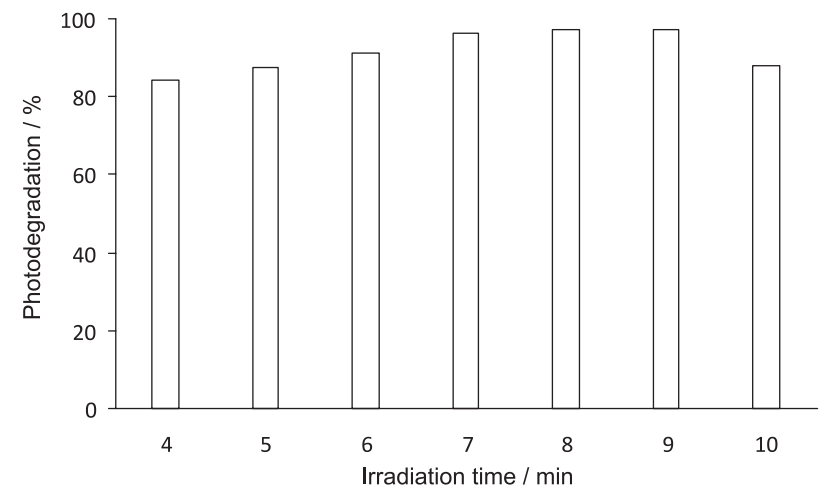

Figure 4. Effect of $\mathrm{pH}$ on the photodegradation of 1,4-BQ at room temperature. $100 \mathrm{mg} \mathrm{L}^{-1} 1,4-\mathrm{BQ}$, amount of photocatalyst $=1.0 \mathrm{~g} \mathrm{~L}^{-1}$, irradiation time $=60 \mathrm{~min}$.

\section{Photoproducts and mineralisation}

GC-MS was used for the identification of 1,4-benzoquinone degradation intermediates. Our study of the degradation intermediates detected only hydroquinone as an intermediate. It is well known that benzoquinones form the brink of ring opening during the decomposition of aromatic compounds. The identification of hydroquinone does not contradict the usual order of formation of intermediates proposed by many authors (phenols, hydroquinones, benzoquinones, carboxylic acids then $\mathrm{CO}_{2}$ and $\mathrm{H}_{2} \mathrm{O}$ respectively), because the formation of hydroquinone from benzoquinone is a reversible process. ${ }^{30,31}$

Mineralisation is the main aim of the photodegradation of 1,4-BQ and this can be followed by measuring the total organic carbon. ${ }^{32}$ Figure 5 shows the TOC and the total inorganic carbon (TIC) concentrations during 1,4-BQ degradation. It would be seen that the amount of TOC steadily decreased with increasing irradiation time, which indicates the disappearance of 1,4-BQ intermediates. On the other hand, the TIC curve shows that the amount of total inorganic carbon was relatively constant. The presence of inorganic carbon is most likely due to the conversion of some organic carbon into inorganic carbon, such as carbonate ions. It can be concluded from Figure 5 that $84 \%$ 
organic carbon is removed from 1,4-BQ solution as $\mathrm{CO}_{2}$. The residual TOC value (16\%) would perhaps indicate the presence of unidentified photoproducts such as aliphatic carboxylic acids, at the end of the reaction.

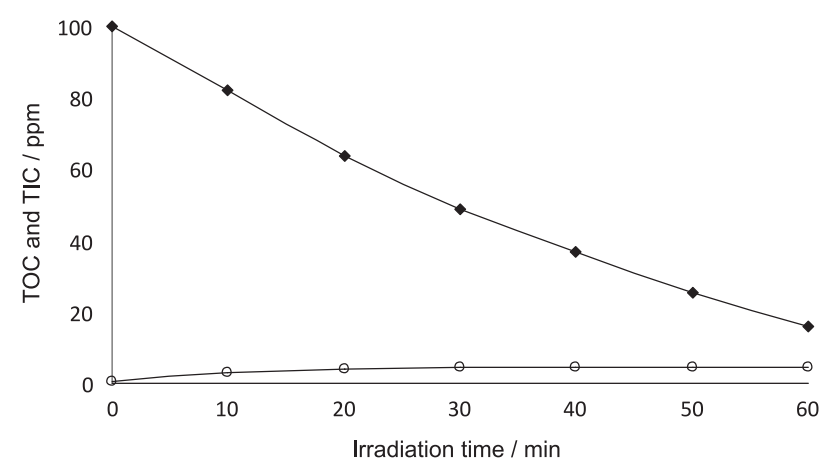

Figure 5. Time course of TOC and TIC during photodegradation of 1,4-BQ, $(\diamond)$ TOC, (O) TIC. Initial conditions: 1,4-BQ concentration $=100 \mathrm{mg} \mathrm{L}^{-1}$, $\mathrm{ZnO}=1.0 \mathrm{~g} \mathrm{~L}^{-1}$ and $\mathrm{pH}=7.55$.

Reusability of $\mathrm{ZnO}$

The reusability of $\mathrm{ZnO}$ photocatalyst for the 1,4-BQ degradation was studied at $100 \mathrm{mg} \mathrm{L}^{-1}$ levels of 1,4-BQ and in presence of $1.0 \mathrm{~g} \mathrm{~L}^{-1} \mathrm{ZnO}$. Other experimental conditions were maintained constant. $\mathrm{ZnO}$ was recovered from reactivity solutions by filtration through $0.45 \mu \mathrm{m}$ PTFE. The $\mathrm{ZnO}$ residue was washed 4 times with distilled water and dried in an electric oven at $96{ }^{\circ} \mathrm{C}$. The dry $\mathrm{ZnO}$ was then reused 4 times in the degradation process. Figure 6 shows the stability of $\mathrm{ZnO}$ during the four cycles (photodegradation \% =97). Remarkable stability of the $\mathrm{ZnO}$ photocatalyst may be readily observed which indicates successful reuse of the photocatalyst.

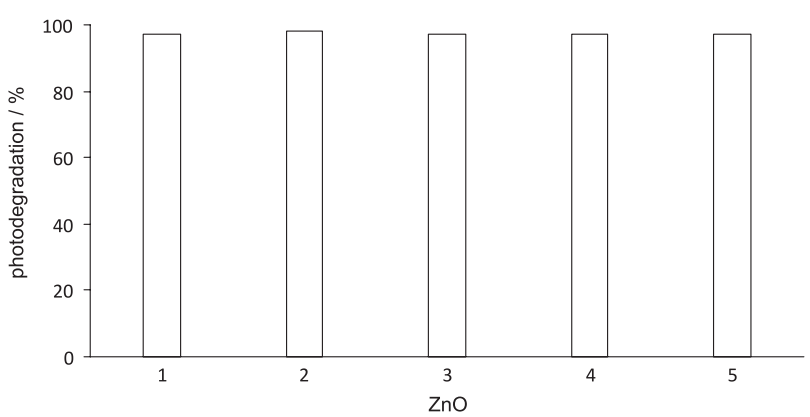

Figure 6. Reusability of $\mathrm{ZnO}$ in 1,4-BQ photodegradation. $\mathrm{Z}$ refers to fresh $\mathrm{ZnO}$ cycle and $\mathrm{Z1}, \mathrm{Z2}, \mathrm{Z} 3$ and $\mathrm{Z} 4$ are reused $\mathrm{ZnO}$ powders numbered according to reuse. Initial conditions: 1,4-BQ concentration $=100 \mathrm{mg} \mathrm{L}^{-1}$, $\mathrm{ZnO}$ concentration $=1.0 \mathrm{~g} \mathrm{~L}^{-1}, \mathrm{pH}=7.55$, irradiation time $=60 \mathrm{~min}$.

\section{Conclusions}

The photocatalytic study of 1,4-BQ in aqueous $\mathrm{ZnO}$ reveals the following advances. First and foremost, maximum photodestruction of 1,4-BQ can be achieved at room temperature, with the $\mathrm{ZnO}$ photocatalyst and 1,4-BQ concentration fixed at $1.0 \mathrm{~g} \mathrm{~L}^{-1}$ and $100 \mathrm{mg} \mathrm{L}^{-1}$, respectively. It should be noted that $1,4-\mathrm{BQ}$ is easily removed from solution. The main aromatic intermediate in the process is hydroquinone. Lastly, it may be concluded that $\mathrm{ZnO}$ is a good catalyst for the removal of quinones owing to its efficiency of destruction and reusability.

\section{References}

1. Fernández-Ibáñez, P.; Malato, S.; De Las Nieves, F.; Catal. Today 1999, 54, 195.

2. Litter, M. I.; Appl. Catal., B 1999, 23, 89.

3. Schmelling, D. C.; Gray, K. A.; Water Res. 1995, 29, 2651.

4. Rathi, A.; Rajor, H. K.; Sharma, R. K.; J. Hazard. Mater. 2003 , 102, 231.

5. Peiró, A. M.; Ayllón, J. A.; Peral, J.; Doménech, X.; Appl. Catal., B 2001, 30, 359.

6. Brezova, V.; Stasko, A.; J. Catal. 1994, 147, 156.

7. Pardeshi, S. K.; Patil, A. B.; Solar Energy 2008, 82, 700.

8. Mai, F.; Chen, C.; Chen, J.; Liu, S.; J. Chromatogr., A 2008, 1189, 355.

9. Lachheb, H.; Puzenat, E.; Houas, A.; Ksibi, M.; Elaloui, E.; Guillard, C.; Herrmann, J.-M.; Appl. Catal., B 2002, 39, 75.

10. Kandavelu, V.; Kastien, H.; Thampi, K. R.; Appl. Catal., B 2004, $48,101$.

11. Chen, C. C.; Lu, C. S.; Chung, Y. C.; J. Photochem. Photobiol., A 2006, 181, 120.

12. Özgür, Ü.; Alivov, Y.; Liu, C.; Teke, A.; Reshchikov, M.; Do an, S.; Avrutin, V.; Cho, S.; Morkoc, H.; J. Appl. Phys. 2005, 98, 041301.

13. Konstantinou, I. K.; Albanis, T. A.; Appl. Catal., B 2004, 49, 1.

14. Akyol, A.; Yatmaz, H. C.; Bayramoglu, M.; Appl. Catal., B 2004, 54, 19.

15. da Silva, C. G.; Faria, J. L.; J. Photochem. Photobiol., A 2003 , 155, 133.

16. Yu, D.; Cai, R.; Liu, Z.; Spectrochim. Acta, Part A 2004, 60, 1617.

17. Akyol, A.; Bayramoglu, M.; J. Hazard. Mater. 2005, 124, 241.

18. Height, M.; Pratsinis, S.; Mekasuwandumrong, O.; Praserthdam,P.; Appl. Catal., B 2006, 63, 305.

19. Mehrotra, K.; Yablonsky, G. S.; Ajay, K.; Ind. Eng. Chem. Res. 2003, 42, 2273.

20. Guillard, C.; Disdier, J.; Herrmann, J. M.; Lehaut, C.; Chopin, T.; Malato, S.; Blanco, J.; Catal. Today 1999, 54, 217.

21. Theurich, J.; Lindner, M.; Bahnemann, D. W.; Langmuir 1996, 12,6368 .

22. Lipczynska-Kochany, E.; Kochany, J.; Bolton, J. R.; J. Photochem. Photobiol., A 1991, 62, 229. 
23. Gaya, U. I.; Abdullah, A. H.; Zainal, Z.; Zobir, M.; Int. J. Chem. 2010, 2, 180.

24. Durand, A. P. Y.; Brown, R. G.; Chemosphere 1995, 31, 3595.

25. Al-Sayyed, G.; D’Oliviera, J. C.; Pichat, P.; J. Photochem. Photobiol., A 1991, 58, 99.

26. Sobczyński, A.; Duczmal, L.; Dobosz, A.; Monatsh. Chem. 1999, 130, 377.

27. Gaya, U. I.; Abdullah, A. H.; J. Photochem. Photobiol., C 2008, $9,1$.

28. Kansal, S. K.; Singh, M.; Sud, D.; J. Hazard. Mater. 2008, 153, 412.
29. Davis, A.; Huang, C.; Water Sci. Technol. 1989, 21,455.

30. Flox, C.; Cabot, P. L.; Centellas, F.; Garrido, J. A.; Rodríguez, R. M.; Arias, C.; Brillas, E.; Appl. Catal., B 2007, 75, 17.

31. Minisci, F.; Citterio, A.; Vismara, E.; Fontana, F.; De Bernardinis, S.; Correale, M.; J. Org. Chem. 1989, 54, 728.

32. Heiland, G.; Mollwo, E.; Stöckmann, F.; Solid State Physics, Frederick, S.; David, T., eds.; Academic Press: New York, 1959.

Submitted: July 23, 2011

Published online: November 22, 2011 